\title{
Wiping Blood from the Walls: Medea's Pleasures of Terror
}

Clark Lunberry

University of North Florida, clark.lunberry@unf.edu

Follow this and additional works at: https://digitalcommons.unf.edu/aeng_facpub

Part of the English Language and Literature Commons

\section{Recommended Citation}

Lunberry, Clark, "Wiping Blood from the Walls: Medea's Pleasures of Terror" (2006). English Faculty

Publications. 5.

https://digitalcommons.unf.edu/aeng_facpub/5

This Article is brought to you for free and open access by the Department of English at UNF Digital Commons. It has been accepted for inclusion in English Faculty Publications by an authorized administrator of UNF Digital Commons. For more information, please contact Digital Projects.

(C) 3-2006 All Rights Reserved

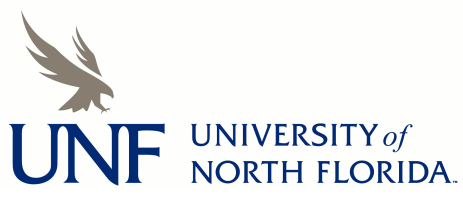




\title{
Wiping Blood from the Walls: Medea's Pleasures of Terror
}

\author{
Clark Lunberry
}

The change of fortune should be not from bad to good, but, reversely, from good to bad. ... Hence they are in error who censure Euripides just because he follows this principle in his plays, many of which end unhappily. It is, we have to say, the right ending.

-Aristotle, Poetics 76

For the stagehand who watches the actors from above and from behind the curtain, even the most tragic spectacle is just another show to be put onbe has seen it all before.

—André Green, "The Psycho-analytic Reading of Tragedy" 141

I was there and then I wasn't. The actors were before me and then they weren't. The curtain opened, it closed, and-in the play of appearances and disappearances-something was seen in the vanishings. Remaining, what I now write is a kind of recollected narrative, a reportorial account of British director Deborah Warner's recent adaptation of Euripides' Medea. As a member of its audience one evening, I look back from the strict vantage of the remembered event, from the dual perspective of having seen the performance, but of seeing it no longer, of having been a spectator to the play, but now being a spectator to my memories of it. For my time in the theatre had at its core an ephemeral dimension easily forgotten, but fundamental: "now you see it, now you don't." Coming and going as it did, Medea (and my seeing of it) nonetheless engendered an unexpectedly rich afterlife that extended beyond its immediate staging, beyond this one particular evening, as the play was later involuntarily recalled, or willfully summoned into posthumous shape and dimension.

Warner's production of Euripides' classic Greek tragedy was first performed in North America at the Brooklyn Academy of Music in 2002, before moving over to Broadway, where I saw it in 2003 at the Brooks Atkinson Theater. The performance I attended was deeply moving and powerfully done, with Medea's familiar story of vengeance, despair, and death progressively building scene by scene, finally coming to a close in all its harrowing emptiness: no hope, no redemption, no return to reason-dark upon dark, seeping into every seam. Like a nothing I'd never seen before.

But then there was more. For that evening, even after the play was finally, formally finished-all of its lines delivered, the dramatic actions carried out, and the curtain fully closed (with many in the audience, like me, shaken by what they had just witnessed)-other events in the theatre were still to unfold. Indeed, actions involving the stage curtain and the curtain call were inadvert- 
ently to extend events beyond Euripides' written conclusion, then on to the unassuming stagehands who literally closed the show. With these additional postperformance activities interrupting, even perhaps transforming, Medea's otherwise profound impact, it was suddenly no longer quite clear where the play's dark ending had ended, or where our seeing was finally to stop.

But before jumping to conclusions and discussing these other extended endings to the evening-the first involving the curtain and the curtain call, the second my recollected memories of Medea-I'll begin with the play itself, looking especially at those horrific moments that led up to the performance's bloody denouement. In Warner's Medea, the actions on the stage culminate in the mother's gruesome murder of her own two children. In a fit of uncontrollable rage and determined vengeance towards her deceitful husband Jason, Medea (played powerfully by Fiona Shaw) is about to perform the unthinkable. Her little boys attempt to flee, running from their mother, realizing what is happening. Medea, however, frantically catches them, gathers them up in her arms and, just off stage and out of sight, stabs them and slashes their throats-screams are heard in the wings, a broad spray of blood flies out and lands upon a glasspartitioned wall, brightly illuminated and immediately draining to the floor.

As spectators to the play, eyewitnesses to the ghastly crimes just committed, we may have anticipated what was coming, and perhaps (like the jaded stagehands André Green describes in one of my epigraphs) we'd even "seen it all before." Yet many were perhaps still caught off-guard (as I certainly was) by the unredeemed brutality of it all taking place right in front of us. And even though the actual act of murder, the slitting of young throats, was unseen-with Euripides in effect shielding us from the sight, sparing us this final obscenity by writing it onto the wings of the stage-the blood and screams effectively fed our eyes, convincing us of having seen and, as such, in the thinking of it, perhaps seeing even more. For, indeed, my eyes that night could barely keep up with the horrors unfolding before them, desiring to see and not to see simultaneously.

And that is the question-to see or not to see-arising that night, arising now. But seeing or not seeing what? Seated in the theatre, what was it that I desired to see on the stage, and what, finally, had my desire seen? And what do I see now, looking back, trying many months later to picture posthumously what decayingly remains of Medea? Might it be, as Green elsewhere notes of the "tragic effect" of theatre, that that which so rapidly happened before me that night was now offering-to be seen-something resembling a "moment of truth so dazzling and so short-lived that it has already passed while one is still waiting for it" (141)? And if so, what was that finally unseeable, unlocatable "truth," however troublingly conceived-its message, its meaning-so violently registered, so momentarily passing? Perhaps such an event- "so dazzling and so short-lived"-might, like the fading fragments of a dream, be retrospectively reconfigured, re-visioned, but stilled or stalled now through mediated reflection.

Covered in the blood of her own children, Medea re-enters the abruptly silenced stage, carrying the slain boys-the youngest over her shoulder, the older under her arm-and plodding forward beneath their dead weight. Calmly, 
she then places them onto the floor at the center of the stage, the lifeless bodies laid out like morbid trophies before us. Moments later, with Jason returned and realizing what has happened, Medea refuses to allow the distraught father to embrace his dead boys, to bury their bodies, to mourn. "I'll lay them in Earth myself," Medea coolly insists. "As for you, / Your life was folly, you'll die / Like the fool you are / So ends our sorry story, yours and mine" (47-48). Pathetically, Jason sits weeping at the front of the stage, summoning the gods, pleading for them- "Zeus, do you hear?"-to witness what has happened (indeed, wishing for the gods to see what we have just seen, appealing for their intervening omniscience). In the play's final hopeless moments, Medea walks lightly about the stage, appearing as if-through the very extremity of her murderous actions, the blunt force of its dead-end conclusions-a heavy load has been lifted from her shoulders. She taunts her grieving husband with the irreversible reality of what she has just proudly accomplished. "My dear, speak up," Medea says teasingly to Jason, "The Gods can't hear" (48). At this cruelest and darkest of godless moments, the play-this "sorry story"-soon ends, the curtain quickly closes.

As I recounted earlier, even after the play had finished and the curtain had closed upon it, events in the theatre that evening had not yet entirely concluded. For as convention would have it, only moments later the curtain opened again onto the now emptied stage; a hearty applause from us in the audience immediately began. Shortly after, the entire cast came forward for the traditional curtain call. First there was Jason, the father, entering from the wings, followed thereafter by others. And finally, with greatest anticipation, Medea herself appeared, along with her two murdered sons; at this point many in the audience began to rise, offering what seemed at the time a richly deserved standing ovation, an exuberant acknowledgement of the astonishing performance just completed, a job well done.

Tenderly, Medea carried the youngest child upright in her arms, with the older one walking closely by her side; she looked down and smiled at the boys, now very much alive, and then-shifting her gaze-out to us in the audience, to whom she gracefully bowed. There was at that moment, clearly, something quite moving about Fiona Shaw's sweet embrace of the live children (an embrace that, just minutes before, Medea had denied Jason of the dead ones) and what seemed her unaffected affection for both of them. Indeed, the frantic tension possessed by all of the actors (and, no doubt, by many in the audience) as the play brutally concluded had been rapidly replaced at this curtain call by an entirely different air of relaxation and reward, professional bodies visibly loosening their crafted holds upon themselves, as though they'd been released from an enfevered dream, restored-all lights up-to the recollected reality of the room, the stage, us in the audience, the familiar space of theatre.

Almost seamlessly, Medea had returned to Fiona Shaw, the boys returned to life, while those of us watching it all were returned to ourselves in the audience (where had we been?). And with the entire cast repeatedly bowing and smiling broadly, all of the actors, in unison-many of them now cheerily handin-hand-then exited the stage for good. This time, however, as the ovations receded and finally stopped, the curtain remained fully opened, the stage now empty, with little to be seen except-quite vividly-that broad spray of blood brightly illumined, glistening still upon the back wall. 
Thinking back on that memorable evening, I can't recall with any degree of certainty whether Fiona Shaw and the two little boys were still covered in blood as they re-entered for the curtain call, or whether they'd quickly changed their clothes before returning to the stage. Such specific recollections seem, like a dream, unreliable to me now. But whether the actors were still bloodied or not (I now picture them both ways, which, of course, can't be right), I do remember well my strongly mixed feelings about suddenly seeing the now-happy cast again in this new light of the post-performance, in the aftermath of all that had just been so disturbingly seen. (And, of the actors' broad smiles directed now toward us in the audience, I recalled King Kreon's wise suspicion of smiling Medea midway through the play, when he said of her, "A raging fury / Is easily policed. But smiles!" [11].) For as much as I wanted to applaud the powerful performance, and at the curtain call, as much as I was moved by Fiona Shaw's sweet embrace of the little boys, part of me very much desired for the curtain to stay closed on this play, with mad Medea remaining madly Medea, grieving Jason as Jason forever grieving: for time to stand still, and for the dead to remain entirely dead, even brutally so.

But why? What had I seen that night that, in spite of its troubling nature, I wished to preserve? (Or might it have been precisely because of that nature that I hoped to preserve it?) Of her earlier poisoning of King Kreon's daughter Glauke, Medea says of the servant's grisly descriptions that "The worse it was, the more I want to hear" (39). For in the elaborate recounting of the tormented deaths, there was for Medea a satisfaction clearly gained, a deep need that was both teased and pleasured by the graphic description (murderous acts, again unseen, but nonetheless seeming so in the telling, in the thinking of them). Likewise, in the theatre that evening I found myself feeling, in a similar vein, much the same, sharing something of Medea's perverse desire to witness more and more of what was, however darkly, unfolding-those young deaths, offstage and just out of sight. The worse it was, the more I wanted to see, and the more I wanted to keep seeing it: to keep the horror there in front of me, to scrutinize it ever more closely. For there was, as long as it lasted, a kind of invigorating, visceral clarity brought on by the performance, the unnerving feeling that, voyeuristically, I was an eager observer of these awful actions. Swept up by a kind of crescendo of accumulated perception (culminating most aggressively in the spurt of blood upon the wall), my eyes - and, in fact, it seemed as if I had become all eyes, my entire body a kind of sentient, perceiving machine-had been progressively, pleasurably trained onto the building ferocity of the murderous events, tunneling in to see ever more sharply what felt like something I shouldn't be seeing, while inciting what Herbert Blau describes as "the desire to see the thing that remains unseeable, whatever the distance, though it is indeed happening there before your eyes" (Audience 287; original italics). The question, however, remains, what might this "thing" be that is so desiringly sought, so ambivalently seen? And what attracts us, draws us (like moth to flame) to such a sight?

Of course, the word "catharsis," the experience of catharsis, comes quickly to mind as a way of explaining, of labeling, something of Medea's strange attractions, and of what Aristotle provocatively described as the "true tragic pleasure" aroused in me that evening, in the events so vividly seen. However, if catharsis-understood by some as a kind of emotional, moral, intellectual purgation or purification-is indeed an appropriate term to apply to my strong 
response to the play, what kind of catharsis might it have been, what was the nature of its peculiar "pleasure," and what, finally, was subsequently purged or purified in the process? Perhaps this illusive Greek term-left so teasingly illdefined by Aristotle ${ }^{1}$ and, more recently, disparaged by some for its (mindlessly) absorptive tendencies ${ }^{2}$ - might now be fleshed out in order to fit or enframe more fully the range of reactions that unfolded for me, not just that evening, but in the weeks and months that followed.

For in the effective afterlife of my memories of Medea, something of that night's cathartic force would seem to have now developed beyond the theatre itself, beyond that single evening. Indeed, like a chemically emerging photograph, an enlarged picture of Medea is slowly coming into view from out of its recollected fragments: but a picture whose field of focus has unexpectedly expanded to include something of the one observing, the spectator seeing himself spectating. Doubled by the temporal distances from the specific event and mirrored by my memories of it, I see Medea increasingly as if from over my own ghostly shoulder, seeing myself see-shaken still by the mother's murders, but now seen shaken, and as such, moved to think my response, to think feelingly both its power and its pleasure. Yes, catharsis, or better yet, a catharsis-at-oneremove: the word divided, reflecting from its distanced vantage something of my own divided consciousness of Medea, split as it is between the "now" of its present remembrance and the "then" of its past impact.

As already described, there were other, more immediate splits and divisions encountered in Medea that night, interruptions of catharsis that were to manifest themselves in the stage curtain and the curtain call. But looking back on this performance, I now wonder if that evening's curtained divisions, offering as they did a kind of ontological delineation of where the theatre was and where it wasn't, might be understood to reflect something of my later, divided memories of Medea. And perhaps those formal interruptions by the curtain of the evening's staged illusions might also now be seen as symptomatic of larger disruptions within the one seeing them, disruptions that-like abrasions upon the eye-both condition and determine what is finally, fleetingly seen.

That night, however, interruption was not at all what I desired as I was so effectively swept away by Medea's powerful presence. With the play abruptly concluded, and then in that brief interval-only seconds, really-between the curtain's closing and its rapid reopening for the curtain call, there was what felt something like a moment of suspended animation, one of indeterminate reckoning. Indeed, the closed curtain had seemed, fittingly, to cover my eyes, drawn like a (mystic) veil across them, leaving me with the tragedy's stark vision of cruelty and carnage graphically imprinted. And these were the immediate impressions so potently received that, however gruesome or gory, I wished to carry with me out of the theatre, as if the dead weight of these images, both possessed and possessing, might in some manner remain palpably, even painfully, present, uninterrupted by that which was to subsequently occur.

If Medea is now remembered much like a dream imperfectly recalled, it is also remembered as a dream from which, on that night, I did not wish to be awakened. For there was from within its imaged horror something approaching Antonin Artaud's "truthful precipitates of dreams," fleetingly encountered, "on a 
level not counterfeit and illusory, but internal" (92). As such, I did not want the curtain to reopen and reveal the crude machinery of the play's making, by which the false had been so effectively fabricated. Having been offered perhaps just a glimpse of what Nietzsche described as "a rapt seeing through wide-open eyes" (33), I wished for the illusion of that reality-however tormented or troublingto stay, to speak, to be, like Hamlet's ghosted father, "something more than fantasy," more than mere theatre.

As almost unbearable to watch as the conclusion of Medea had been, the brutal ending still very much struck me, as Aristotle had described such a tragedy, as "the right ending" (76). While the interruption caused by the curtain call, with all of its attendant conventions, felt like a de facto addendum to the play, a wrong ending to the evening. For the emotional, atmospheric effect that was so quickly created by this curtain call returned me (whether I liked it or not) to the shared event itself, back into the collective fold of the audience, and out of what had felt like the cathartically isolating impact of those final murderous moments of the play-when, however briefly, it had seemed I was sitting alone in the theatre, isolated within the disorientations of my own troubled response to what I was witnessing, hollowed out by the sights just seen. Signified, however, by the curtain call itself, in the sudden shift away from the gripped witnessing of tragedy, to the enthusiastic applauding of the performance of tragedy, we had all been quickly returned to the more familiar realm of theatre, where, as Aristotle lamented, "the deadliest of enemies quit the stage as friends at the close, and no one slays or is slain" (77).

Anthony Kubiak has noted that "theatre's perverse claim to truth is that it is not 'real' but is a true perjury that is determined and upheld by the conventions of the stage. But theatre must suppress this claim to truth as it pursues its illusions in the double bind-it can only find its truth in an illusion, and thus what is "real' ontologically is false empirically" (28; original italics). In the case of Medea and me, it was as if this play's graphic violence had empirically given with the one hand, but then ontologically taken with the other; the cathartic emotions were briefly felt, the obscenity seen, but then quickly-as with the drop of a curtain-I and the rest of the audience were reassured that it was all simply a play, mere make-believe. As Kubiak later noted, and critiqued, "This is precisely the double function of theatre: to institutionalize . . violence, while at the same moment diffusing its resistances" (94).

Yes, Medea's blood was not blood, and the deaths were not deaths. But neither were they nothing, or merely that. But what had they been? And what were they now? For even institutionalized and diffused (as Kubiak characterizes it), might Medea's staged violence have served, still, some revelatory purpose, exposing-like a tender nerve-a metatheatrical dimension through its deliberately perjurous techniques, its "double function" of playfully inflicting pain, painfully inflicting play? And had the theatrical event, finally denying its own illusions (by interrupting them), perhaps returned us, shaken but restored, to our own illusions, those more densely, stealthily compacted fantasies that so firmly convince us of our own veracity-theatre onto theatre, theatre onto ourselves? If so, what may have thus been retrospectively uncovered that evening, even purged into view by the performance's painful extremities, were those invisible determinants of seeing itself, lines of sight extending-like electrically charged alternating currents-in that ethereal space between the stage and the audience, and through which perception's enabling energies were finally to connect and suspend. 
Concerning the performance of pain and its apparent impact, Herbert Blau asks, "In what sense is the pain to be understood? absorbed? felt? grasped by the intelligence? .. . If the pain is to have any meaning at all in what we take from the theatre, how much of it are we to experience in the performance? how intensely or unsparingly? in what ways are we to encounter the reality of it there?" (Audience 179; original italics). Blau's questions here are in many ways my own, as I wonder how Medea's painful representations are to be understood, absorbed, felt, "grasped by my intelligence," while also, later, being represented again through my own writing and recollection. But I also recognize a possible conflict or contradiction in the representational directions that so much of my analysis has taken. Indeed, in speaking of Deborah Warner's production that evening as I have, it might sound as if what I saw in the theatre that night wasn't experienced as a representation at all, but instead as an unmediated presentation of pain itself. For what I've described of the troubling performance is in many ways my own quite conventional absorption into what was, for me, this play's utterly persuasive illusions (and my desire for them to uninterruptedly persist). What I experienced that night was even, I suppose, my rather innocently affective engagement with Medea's make-believe violence, clearly confusing the fake blood for blood, the staged slaughter for slaughter.

However, what intrigues me now, with hindsight, is that (in spite of my own best—call them Brechtian-defenses) I nonetheless found myself that night, for as long as it lasted, fully and pleasurably caught up in this tragedy's tragedy. Indeed, my disbelief was more than willingly suspended, even willfully so, wishing for that curtain to stay fully closed on this play, so as to preserve and protect the illusion's vivid, violent reality. For there was, in the heat of the play's bloodiest moments, the immediately felt conviction that I was witnessing something dangerously real, though obviously false. And in that fabricated presence, there was-mysteriously-a kind of joy, a physical exhilaration in the affective sense of an awakening, an unveiling of seeing itself (even if it had been, finally, an awakening in the midst of a persisting theatrical dream). Hearing the murders narrated, I gripped the handrests of my chair ever more tightly and felt my pulse racing, as my eyes were made to see beyond, or into, or around, what had perhaps always, already been seen (and had, therefore, not been seen at all), as the blinding habits of my everyday vision were momentarily cut and eclipsed by the excruciating sight before me.

But how, I now wonder, aside from the sheer artfulness of the eventEuripides' powerful story, Warner's elegant staging, and Fiona Shaw's stunning performance-am I to account for, even justify, the force of what I saw that evening and for my nearly guilty pleasure in feeling it so deeply: guilty on the level of enjoying the horror (like slowing down at the scene of an awful auto accident), guilty in the knowing that I'd once again been duped by theatre, the wool pulled (like a curtain) over my eyes? How am I to reconcile my apparent absorption into Medea with my awareness of the performance of that performance? And have my written recollections of that evening, however imperfect and incomplete they might be, brought me any closer to understanding the power and meaning of that painful play, the nature and necessity of its tortured representations, as well as the kind of reconfigured catharsis that it would seem to have finally afforded me?

Perhaps my reflections have led me, as if through the delineations achieved through a kind of dreamwork, towards something unexpectedly revealing and 
instructive, perhaps even cathartically charged, in offering a redirected form of perception that refracts back onto the one doing the seeing, onto the seer himself. For could it be that in being duped by theatre, in having been so agreeably deceived-indeed, in Aristotle's terms, even tragically pleasured by Medea's graphic obscenities - that something of the outer limits of representation's defining barriers had somehow been reached, a (bloodied) boundary bumped up against?

As such, the stage curtain's occluding movements might now be imagined as analogous to the opening and closing of eyes (or even the fearful shielding of them). For in the abrupt disruption of my seeing by the curtain and the curtain call, something of seeing itself appears to have been revealed that night (and thus, another less tangible kind of curtained awareness belatedly opened). Seen in this manner, I may indeed have inadvertently passed through a kind of determinative looking-glass, where, as Blau describes it, the pain of the play was finally given its particular meaning, but a "meaning only there, as nothing but representation, painful only in that-as it works on behalf of the invisible to distort our vision-it perpetuates its own dominion?" (Audience 179; original italics). From this eclipsing vantage, I can see that there was, clearly, something more to my bedazzled reaction to Medea and my subsequent uneasiness with the curtain call, something more there than meets the naked eye, and my own naked responses to it. Stained by such a sight and subsequently doubled by its mirroring divisions, these memoried responses might now be understood to signal or speak of a more encompassing kind of perceptual event immediately encountered that evening, while indeed returning me to representation's "perpetuated dominion."

And perhaps it is here, with the performance and the post-performance now understood as one virtually seamless event, that André Green's "moment of truth" spoken of earlier is to be most vividly located and defined, while also finally bringing into sharper focus the catharsis spoken of earlier, a catharsis-atone-remove. For in my desire to see what perhaps shouldn't be seen (because of its very obscenity) - a desire that had been poked and prodded, even necessitated by the violent extremities of the performance itself, and by what Green calls the still "hallucinatory value of representation" (140)—I had, in the final account, been aggressively positioned to see something of my own desire, seeing itself seen within the strict confines of theatre's own reflecting dimension. In fact, recognizing the practical, performative necessity of Medea's brutality, it is as if my eyes that night had been violently thrust up against the very "circular limit" of what Jacques Derrida so vividly describes as the "closure of representation" (250), a closure that can perhaps now be partially, materially designated by the curtain itself as it opens and closes before us. And if, as has been well noted, we see in the shape of our desires, then what this performance and its curtained movements later revealed to me was a shape already familiar to me, something of myself staring back, forcing my eyes to reveal themselves to themselves, or what Green describes as "the negative hallucination in which the subject looks at himself in the mirror and sees all the elements of the setting around him, but not his own image" (140).

Looking back, I now recognize that it was through those apparently peripheral theatrical conventions of the curtain and the curtain call that the conventions of my reveries had indeed been disrupted and then revealed, my dreamy desires delineated, finally unveiling such a sight onto sight-a vision first of 
blood, but then of bloodied vision, "blooded," as Herbert Blau describes the Hamletic end of such a scene, "with nothing but thought" (Blooded xx). While the curtain's presence can, at this point, be understood not to have blocked my vision, but to have mirrored it, not simply to have interrupted catharsis, but to have caused a kind of catharsis of interruption. As a constituted spectator, seeing negatively now, I had effectively-indeed, cathartically-vanished in the heat of my own perceivings, at "the invisible frontier where the spectator's gaze meets a barrier that stops it and sends it back . . . to the onlooker, that is, to himself as source of the gaze" (Green 138). Seen in retrospect through bloodshot eyes, I picture Medea now in all its harrowing power and beauty, not only as the performance of pain and tragedy that it certainly was. But it is also seen as a circularly enclosed representation of representation that is finally mirroring me in my desire to see, exposed as a kind of "negative hallucination." With this reflexive revelation reflecting, perhaps something of Aristotle's own "tragic pleasure" has now been reconfigured to reveal itself revealing itself, like a curtain opening into its own pleated folds.

Coda: Following Medea's final curtain call that night, the rousing applause eventually ended and gradually those of us in the audience prepared to leave. As I've already noted, the curtain was left open, leaving us all as we departed with a view of the emptied stage, littered with props and stained with blood. This was the crude sight before us as we began to leave the theatre: a depleted space, its violent energies spent. However, whether it was intended or not, one of the oddest, perhaps accidental scenes of the evening still remained to be seen, as if from the corners of our eyes.

Following both the play and the subsequent curtain call, I had stayed seated for some time waiting for the crowd to thin out, enjoying my final moments in the theatre and reflecting upon all that had just been so pleasurably endured. Finally, I stood up; as I moved towards the door, I noticed two stagehands with mops and buckets in hand walk out to where, just moments before, Medea's horrors had unfolded, and also where the actors had taken their final curtain call. Diligently, and with a seeming indifference to the audience's departure, they began wiping the blood from the wall, mopping it up from the floor. Scrubbing away, they worked with real efficiency and within minutes the stage was entirely clean again, cleared of any incriminating evidence. No doubt there was the very practical desire to clean up the bloody mess before it dried entirely, to ready the stage for tomorrow's performance, the next rendering of Medea's savage act. But beyond the merely practical, one might imagine as well that the stagehands were accomplishing something even more ontologically fundamental: wiping the slate clean, resetting the stage for representation's continuing representation.

Gary Shapiro, in his recent book Archaeologies of Vision, writes of the Nietzschean illusions of theatre that position the spectator on the precipice of an abyss, offering momentary illusions of clarity while staring into that emptiness; "beautiful illusions, but illusions nonetheless." Shapiro continues, however, by pointing out,

There is no theatre without vision; as we are often reminded, our words theory and theatre derive from the Greek theoria that signifies the act of 
beholding or witnessing. . . In the theatre, the site of beholding, it is possible to construct a kind of machinery for seeing, one that, like a camera obscura, uses the extremes of light and dark to produce a model form of vision that will both lead us into the depths and provide a shining escape from the nausea and vertigo they provoke. (129-30)

In the theatre that night, as I watched the stagehands enter from the wings and go about their mundane but important work, yet another layer of the "machinery" of theatre inadvertently revealed itself to me. And this was, of course, part and parcel of the same mechanism that had just moments before led me into Medea's dark depths, into the very vertigo that Shapiro describes, a kind of mechanized nausea from which I could then "escape."

If the curtain call that night had initially seemed a kind of interrupting addendum to the play itself, one that had retrospectively unveiled something of my own seeing to me, then the stagehands' dutiful cleaning of the stage could now be understood as an addendum to that addendum, yet another revealing scene before I was to leave the theatre entirely. And in this de facto final act of the evening, the now-extended event had finally ended in this endlessly bloody manner, its very substance-factual or fake, dried or still glistening-dimensionally cast in my desiring imagination, with Medea projecting still in its own self-reflecting, self-revealing capacity.

Clark Lunberry, Assistant Professor of English at the University of North Florida, has written widely on the interrelations of the arts and literature, with recent publications in Critical Inquiry, Mosaic, and Discourse, as well as a book of poetry, StonePoems (1999). He is now completing a book manuscript on silence $/$ absence in the arts.

\section{Notes}

This essay is dedicated to my dear friend, Amelia Arenas.

1. Indeed, there are but brief references to catharsis in Aristotle's entire Poetics, and even those leave much to the imagination as to what he is actually describing. The uncertainty surrounding the term has thus engendered for centuries scholarly speculation as to Aristotle's intended meaning.

2. Bertolt Brecht in particular despised the whole idea of catharsis, describing it as both disempowering and "barbaric."

\section{Works Cited}

Aristotle. Aristotle's Poetics. Trans. S. H. Butcher. New York: Hill and Wang, 1961.

Artaud, Antonin. The Theater and Its Double. Trans. Mary Caroline Richards. New York: Grove P, 1958.

Blau, Herbert. The Audience. Baltimore: Johns Hopkins UP, 1990. 
Blooded Thought: Occasions of Theatre. New York: Performing Arts Journal Publications, 1982.

Derrida, Jacques. Writing and Difference. Trans. Alan Bass. Chicago: U of Chicago P, 1978.

Euripides. Medea. Trans. Kenneth McLeish and Frederic Raphael. New York: Theatre Communications Group, 1995.

Green, André. "The Psycho-analytic Reading of Tragedy." Memesis, Masochism, and Mime: The Politics of Theatricality in Contemporary French Thought. Ed. Timothy Murray. Trans. Alan Sheridan. Ann Arbor: U of Michigan P, 1997.

Kubiak, Anthony. Stages of Terror: Terrorism, Ideology, and Coercion as Theatre History. Bloomington: Indiana UP, 1991.

Nietzsche, Friedrich. The Birth of Tragedy. Trans. Francis Golffing. New York: Anchor Books, 1956.

Shapiro, Gary. Archaeologies of Vision: Foucault and Nietzsche on Seeing and Saying. Chicago: U of Chicago P, 2003. 